\title{
Evaluating Satisfaction of Citizens on Quality of Public Administration Services in the Central Highlands of Vietnam
}

\author{
Dang Van My ${ }^{1, *}$, Nguyen Thi Thuy Hanh ${ }^{2}$ \\ ${ }^{1}$ Director, Business Administration Faculty, the University of Da Nang, Campus in Kon Tum, Vietnam \\ ${ }^{2}$ Lecturer, Business Administration Faculty, the University of Da Nang, Campus in Kon Tum, Vietnam
}

Copyright $\bigcirc 2018$ by authors, all rights reserved. Authors agree that this article remains permanently open access under the terms of the Creative Commons Attribution License 4.0 International License

\begin{abstract}
In order to assess the satisfaction of the citizen on the quality of public administrative services in the Central Highlands, research interviewed a randomized direct of 2000 citizens in 2017. Using SPSS to analyze EFA and regression, the results of the study have identified six groups of factors that affect the satisfaction of citizens is reliability; procedures; cost and time; employers, civil servants and officials; facilities and care, supporting. All factors have a positive impact on people's satisfaction, especially procedures; supporting; cost and time are the most significant factors. Therefore, research has recommended some solutions to improve people's satisfaction, such as completing the process; improve the quality of cadres, civil servants and officials; promote care and support the people.
\end{abstract}

Keywords Public Administration Service, the Central Highlands, Satisfaction, Quality, Citizen

\section{Introduction}

The Central Highlands includes 5 provinces such as Dak Lak, Gia Lai, Kon Tum, Dak Nong, Lam Dong. In 2016, its total population accounted for $6 \%$ of the population with $5,695,074$ people, and its area accounted for $16 \%$ of the whole country (according to the General Statistics of Vietnam [5]). The Central Highlands has become a major crop of industrial crops of Vietnam. There are many types of agricultural products which are the main products in our country's exports such as coffee (Central Highlands is the largest area which plants coffee (accounting for more than $90 \%$ of area and $93 \%$ of total coffee production in Vietnam), the second largest area in the country in rubber production after the South East (26\% of the country's area and $19 \%$ of the country's total rubber production) and $70 \%$ of pepper production in the whole country) (General Statistics of Vietnam [5]). Besides, this is also an area aiming at developing socio-economics national defense, security, foreign affairs and the ecological environment of the country. The central highlands is located in the central part of the mountainous area of Southern Indochina, with natural corridors connecting southern Laos, northeastern Cambodia, and an interconnected system of roads connecting the central coastal provinces. There are international borders on the East-West corridor and not too far from the deep-water seaports like Dung Quat, Chan May, Nhon Hoi ... in spite of such remarkable achievements, the socio-economic conditions of the Central Highlands still face many difficulties and don't correspond to the potential and advantages of the region. In fact, the provincial competitiveness index (PCI) of the Central Highlands provinces is very low. In 2017, Dak Lak ranked 31st out of 63 provinces, Lam Dong ranked 22th, Kon Tum ranked 61th, Dak Nong ranked 63rd (PCI [16]). Besides, public administration service is mainly handcraft (Hoai Tien [8]).

Moreover, studies on public administration service satisfaction have not been paid much attention. There are less official studies on the satisfaction of citizens in the Central Highlands on the quality of public administrative services. Therefore, this study is very necessary in assessing the satisfaction of organizations and individuals with respect to public administrative services in order to determine the level which they benefit from public administrative services, promote their ownership and participate in the development of administrative services. Improving the quality of administrative services is also a key objective identified by the Party and State in the Prime Minister's Decision No. 225 / QD-TTg approving the State administrative reform plan in the period 2016-2020. The results of the study will show the factors that affect people's satisfaction, thus recommending some solutions to provide better public administration services. 


\section{Model of Service Quality Measurement}

Public administrative services are services related to law enforcement activities, not for profit purposes, granted by competent state agencies to organizations and individuals in the form of valid legal documents in the areas governed by that government agency (Government [6]). Bovaird and Loffler [1] argue that high quality public administration not only increases customer's satisfaction with public services but also builds public trust through transparency. Assessing public service provision must be understood as a catalyst of accountability, of civil society through citizen action and other interest groups.

International scientists have been interested in researching customer's satisfaction for service quality a long time ago. Grönroos[7] pointed out three points in the service quality model as follows: first, distinguishing functional quality and technical quality; Second, the important role of in service provision and third; The perception of service quality the customer's perceptions of service and the difference between these evaluations and the expectations of customer service. Based on the idea of Grönroos[7], Parasuraman et al.[15] proposed a five-gap model. According to this study, any quality service is also perceived by customers based on the following 10 factors: reliability, responsiveness, serviceability, accessibility, history, communication, credibility, safety, understanding customers, tangible means. Subsequently, Parasuraman et al. [14] formulated a new five-component model known as the SERVQUAL model. This model includes the following factors: reliability, responsiveness, tangible means, service capacity, and empathy. Accordingly, the quality of service is determined as follows:

Quality of Service $=$ Perceived Level - Expected Value.

Kotler [9] shown that satisfaction is the feeling of pleasure or despair of a person derived from a sensory comparison with expectations about the quality of a product or service.

\section{Model of Customer Satisfaction Evaluation}

Quality of service and customer satisfaction is related. According to Oliver [13] and Tse and Wilton [22] satisfaction is the response of the consumer to the desired response, or the customer's reaction to the difference between the desired and perceived level of use of the product / service. However, according to two studies by Cronin and Taylor [4] and Seth et al. [19] the perception of service quality leads to customer satisfaction.

The typical customer satisfaction survey models are such as the CSI Customer Satisfaction Index model; American model of satisfaction index, ACSI and European model of satisfaction index, ECSI. The CSI model is used to measure customer satisfaction for industries and businesses in many developed countries around the world. The American Model of Satisfaction Index (ACSI), perceived value is influenced by perceived quality and customer expectations. Then, the expectations of customers have a direct impact on the quality of feeling. ECSI Satisfaction Index, ECSI customer satisfaction is the combined effect of four visual elements, perceived value, and perceived quality of both tangible and intangible. Typically, the ACSI is generally applicable to the public sector, while the ECSI is often used to measure products and industries.

The importance of enhancing people's satisfaction with public administration services is the foundation and motive for public sector to carry out its regular activities, increasing efficiency of the state management. Tran Thi Thanh Tam [20] indicated that efforting to improve the effectiveness of the administrative divisions of the "one-stop shop" are one of the key objectives of the reform of administrative procedures which sets the index of the level of satisfaction of people is the key solution. Determining the level of satisfaction is a key indicator to gauge the attitudes of the judicial personnel directly serving the people. There are many studies assessing citizens' satisfaction with public administrative services in Vietnam. Most of these studies focus on only one city such as Nghe An, Hanoi, Hau Giang, Da Nang such as Chau Dam Trinh [2], Nguyen Thi Tram Anh và Nguyen Dinh Manh [12], Vu Quynh [22] and Che Viet Phuong [3], Ngo Dinh Trang [11]. Lê Dân [10] determined the factors affecting the quality of service, a proposed model for assessing satisfaction. In addition, a survey plan is used as a basis for evaluating the performance level of satisfaction of citizens and organizations on public services. However, according to the authors' understanding, there is less study on the satisfaction of public administrative services in the Central Highlands. Master dissertation of Tran Quoc Huy [19] surveyed 350 citizens in Konplong, Kon Tum province to assess the level of satisfaction of people on public administrative services. The results suggested a six-factor model including reliability, procedures, staff, costs and time, facilities and supportive care. Therefore, the article will fill the gaps and point out the factors that affect the satisfaction of citizens in the Central Highlands. The Central Highlands which is bordered by Quang Nam Province to the North, Quang Ngai, Binh Dinh, Phu Yen, Khanh Hoa, Ninh Thuan and Binh Thuan to the East, Dong Nai, Binh Phuoc, bordered by Attapeu (Laos) and Ratanakiri and Mondulkiri (Cambodia) provinces has an important strategic position in Vietnam. Being identified as one of the six major economic regions of the country, the Central Highlands has formed a large farming area of important industrial crops, which now account for a large share of Vietnam's agricultural exports such as coffee, rubber, pepper ....

In reality, the provincial competitiveness index (PCI) of the Central Highlands provinces is very low. In 2017, Dak Lak ranked 31st out of 63 provinces, Lam Dong ranked 
22th, Kon Tum ranked 61th, Dak Nong ranked $63^{\text {rd }}$ (PCI [16]).

Based on previous studies, the proposed model consists of 6 independent factors with 27 observation variables and 1 dependent factor with 5 observed variables (Table 2).

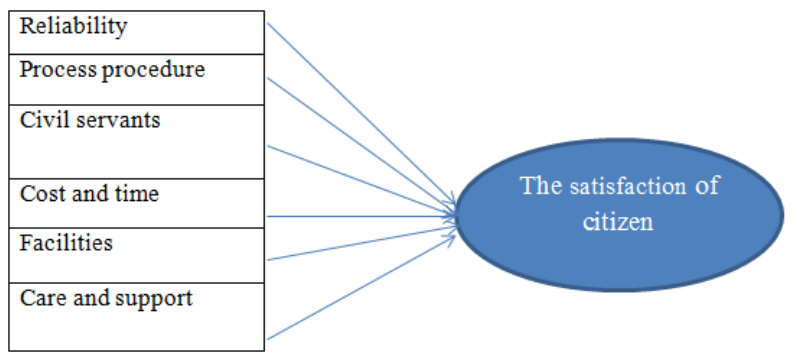

Figure 1. Research model

Based on the model, the hypotheses are the following:

H1: The reliability component has a positive correlates with the customer satisfaction.

H2: The process procedure component has a positive correlates with the customer satisfaction

H3: The civil servants component has a positive correlates with the customer satisfaction

H4: The cost and time component has a positive correlates with the customer satisfaction

H5: The facilities component has a positive correlates with the customer satisfaction

H6: The care and support component has a positive correlates with the customer satisfaction

\section{The Methodology}

The research was conducted in 2017 in two main steps: preliminary research and formal study. Step 1, the study was conducted through group discussion and 50 customer interviews to adjust and add observation variables. Step 2, to measure the influence of factors on customer satisfaction. Data were collected through direct interviews using questionnaires. The respondents were citizens using public administrative services aged 18 years and over.

The total number of people interviewed randomly chosen was 2000 of which 400 persons were in each province. Those are localities in the province with high population and a large number of enterprises and households.

Table 1. Distribution of research samples by province

\begin{tabular}{|c|c|c|c|}
\hline No & Province & Quantity & Percent \\
\hline 1 & Kon Tum & 400 & $20 \%$ \\
\hline 2. & Gia Lai & 400 & $20 \%$ \\
\hline 3. & Dak Nong & 400 & $20 \%$ \\
\hline 4. & Dak Lak & 400 & $20 \%$ \\
\hline 5. & Lam Dong & 400 & $20 \%$ \\
\hline
\end{tabular}

The scales for the factors in the model are shown in Table 2, using SPSS to test the scale by the Cronbach's alpha coefficient for conducting EFA analysis and regression to evaluate the satisfaction of citizen on the quality of public administrative services in the Central Highlands.

Table 2. Scale of the research model

\begin{tabular}{|c|c|c|}
\hline Scale & Variables & $\begin{array}{c}\text { Encode } \\
\text { variables }\end{array}$ \\
\hline \multirow{5}{*}{ Reliability } & $\begin{array}{l}\text { 1. The public trust the quality of } \\
\text { public administrative services }\end{array}$ & DTC1 \\
\hline & $\begin{array}{l}\text { 2. People are very confident in the } \\
\text { use of public administrative } \\
\text { services }\end{array}$ & DTC2 \\
\hline & $\begin{array}{l}\text { 3. Public administrative services } \\
\text { always carry out what they have } \\
\text { committed }\end{array}$ & DTC3 \\
\hline & $\begin{array}{l}\text { 4. Information of the people is } \\
\text { always good security }\end{array}$ & DTC4 \\
\hline & $\begin{array}{l}\text { 5. The service provides people } \\
\text { with high accuracy }\end{array}$ & DTC5 \\
\hline \multirow{6}{*}{$\begin{array}{c}\text { Process } \\
\text { procedure }\end{array}$} & $\begin{array}{l}\text { 1. Procedures of publicity and } \\
\text { transparency }\end{array}$ & QT1 \\
\hline & $\begin{array}{l}\text { 2. Current application procedures } \\
\text { are simple to implement }\end{array}$ & QT2 \\
\hline & $\begin{array}{l}\text { 3. Procedures are properly dealt } \\
\text { with regulations }\end{array}$ & QT3 \\
\hline & $\begin{array}{l}\text { 4. Procedures for reasonable } \\
\text { settlement }\end{array}$ & QT4 \\
\hline & $\begin{array}{l}\text { 5. Information on services is } \\
\text { provided in full }\end{array}$ & QT5 \\
\hline & $\begin{array}{l}\text { 6. Waiting time and transaction } \\
\text { processing is appropriate }\end{array}$ & QT6 \\
\hline \multirow{5}{*}{ Civil servants } & 1. Processing accurate records & DN1 \\
\hline & 2. Very responsible in the work & DN2 \\
\hline & 3. Have a friendly attitude & DN3 \\
\hline & 4. Polite, agile behavior & DN4 \\
\hline & 5. Always be fair to everyone & DN5 \\
\hline \multirow{4}{*}{ Cost and time } & $\begin{array}{l}\text { 1. Full public fees and charges for } \\
\text { workplaces }\end{array}$ & $\mathrm{CP} 1$ \\
\hline & $\begin{array}{l}\text { 2. To collect fees and charges in } \\
\text { accordance with regulations }\end{array}$ & $\mathrm{CP} 2$ \\
\hline & $\begin{array}{l}\text { 3. The time for returning the } \\
\text { dossier-settling results is right }\end{array}$ & $\mathrm{CP} 3$ \\
\hline & $\begin{array}{l}\text { 4. Waiting time for receiving and } \\
\text { processing applications quickly }\end{array}$ & $\mathrm{CP} 4$ \\
\hline \multirow{3}{*}{ Facilities } & $\begin{array}{l}\text { 1. Place convenient, easy to find, } \\
\text { easy to see }\end{array}$ & $\mathrm{CS} 1$ \\
\hline & $\begin{array}{l}\text { 2. Standby area and receive } \\
\text { separate results }\end{array}$ & CS2 \\
\hline & 3. Modern equipment & $\mathrm{CS} 3$ \\
\hline \multirow{4}{*}{$\begin{array}{l}\text { Care and } \\
\text { support }\end{array}$} & $\begin{array}{l}\text { 1. Have counseling, explain to the } \\
\text { people }\end{array}$ & HT1 \\
\hline & 2. There is a hotline & HT2 \\
\hline & $\begin{array}{l}\text { 3. Procedures for resolving } \\
\text { scientific complaints }\end{array}$ & HT3 \\
\hline & $\begin{array}{l}\text { 4. The information system is } \\
\text { appropriate }\end{array}$ & HT4 \\
\hline \multirow{5}{*}{$\begin{array}{c}\text { The } \\
\text { satisfaction of } \\
\text { citizen }\end{array}$} & 1. Satisfying the civil servants & HL1 \\
\hline & 2. Satisfaction with the process & HL2 \\
\hline & 3. Satisfied with the facilities & HL3 \\
\hline & $\begin{array}{l}\text { 4. Satisfaction about care and } \\
\text { support }\end{array}$ & HL4 \\
\hline & $\begin{array}{l}\text { 5. Satisfying the cost of } \\
\text { participating in public } \\
\text { administrative services }\end{array}$ & HL5 \\
\hline
\end{tabular}




\section{Research Results}

\subsection{Descriptive statistics analysis}

Table 3. Statistical results based on gender and occupation

\begin{tabular}{|c|c|c|c|c|}
\hline \multirow{2}{*}{ Occupation } & \multicolumn{3}{c|}{ Gender } \\
\cline { 3 - 5 } & Female & Male & Total \\
\hline \multirow{2}{*}{ Students } & Quantity & 115 & 199 & 314 \\
\cline { 2 - 5 } & Percent \% & $14.60 \%$ & $16.50 \%$ & $15.70 \%$ \\
\hline \multirow{2}{*}{$\begin{array}{c}\text { Civil } \\
\text { servants }\end{array}$} & Quantity & 330 & 350 & 680 \\
\cline { 2 - 5 } & Percent \% & $41.80 \%$ & $28.90 \%$ & $34 \%$ \\
\hline \multirow{3}{*}{ Laborers } & Quantity & 297 & 584 & 881 \\
\cline { 2 - 5 } & Percent \% & $37.50 \%$ & $48.30 \%$ & $44.05 \%$ \\
\hline \multirow{2}{*}{ Tothers } & Quantity & 50 & 75 & 125 \\
\cline { 2 - 5 } & Percent $\%$ & $6.33 \%$ & $6.20 \%$ & $6.25 \%$ \\
\hline & Quantity & 790 & 1210 & 2000 \\
\cline { 2 - 5 } & Percent $\%$ & $100 \%$ & $100 \%$ & $100 \%$ \\
\hline
\end{tabular}

The research results, 2017
The total number of questionnaires received was 2000 ( $100 \%$ of total votes). The number of male citizens is 1210 , reaching $60.5 \%$, while the number of female citizens is 790 accounted for only $39.5 \%$.

Statistical results based on gender and occupation, are presented in Table 3. Accordingly, the highest number of laborers, accounting for $44.05 \%$; next to civil servants (34\%); are students and others. Laborers are people who are working for non-public units such as private enterprises and production households.

Table 4 shows the results of disaggregation by gender and type of services, in which social policies have the highest rate of $44.75 \%$; Business registration and other services accounted for $33.75 \%$ and $21.5 \%$, respectively. In fact, citizens in the region often use public administrative services such as notary papers such as birth certificates, diplomas, resumes, and papers purchase land

Table 4. Statistics of gender and type of services

\begin{tabular}{|c|c|c|c|c|}
\hline \multicolumn{2}{|c|}{ Type of services } & \multicolumn{2}{c|}{ Gender } \\
\cline { 3 - 5 } & Female & Male & \multicolumn{2}{c|}{ Total } \\
\hline \multirow{2}{*}{ Social policies } & Quantity & 280 & 615 & $44.75 \%$ \\
\cline { 2 - 5 } & Percent $\%$ & $35.40 \%$ & $50.80 \%$ & 675 \\
\hline \multirow{2}{*}{ Business registration } & Quantity & 185 & 490 & $33.75 \%$ \\
\cline { 2 - 5 } & Percent $\%$ & $23.40 \%$ & $40.50 \%$ & 430 \\
\hline \multirow{2}{*}{ Others } & Quantity & 325 & 105 & $21.50 \%$ \\
\cline { 2 - 5 } & Percent $\%$ & $41.10 \%$ & $8.70 \%$ & 2000 \\
\hline \multirow{2}{*}{ Total } & Quantity & 790 & 1210 & $100 \%$ \\
\hline
\end{tabular}

The research results, 2017

\subsection{Test of the Scale by Cronbach's Alpha}

The Cronbach Alpha coefficient is used to classify the variables that do not match the variables, item-total correlation 0.6. The results of Alpha factor analysis for each factor are as follows:

- The Cronbach Alpha coefficient of the reliability component is 0.817 , so the scale is standard. At the same time, the observed variables have variable coefficients- sum higher and greater than 0.3 , so the variables are satisfactory and reliable.

- The Cronbach Alpha factor of the process factor is 0.8874 , so the scale is standard. At the same time, the variables have variable coefficients - the sum is high and $>0.3$, so the variables are satisfactory.

- Cronbach Alpha coefficient of cadre factor is 0.8003 , so the scale is standard. The variables have variable coefficients - the sum is high and $>0.3$ so the variables meet the requirements and reliability.

- Cronbach Alpha factor of cost and time factor; facilities and support for people are $0.783 ; 0.699$ and 0.801 . The item-total correlation coefficient of all component variables was greater than 0.3 , which was satisfactory.

- The Cronbach Alpha coefficient of satisfaction of citizens is 0.765 , so the reliability of the scale and the correlation coefficient of the observed variables are greater than 0.3 . species

As a result, the six components of the Citizen Satisfaction Scale are statistically significant and reach the required confidence coefficient. Therefore, 6 components are eligible to continue to be used in subsequent analyzes 0 
Table 5. Rotated Component Matrix ${ }^{\mathrm{a}}$

\begin{tabular}{|c|c|c|c|c|c|c|}
\hline & \multicolumn{6}{|c|}{ Component } \\
\hline & 1 & 2 & 3 & 4 & 5 & 6 \\
\hline Procedures are properly dealt with regulations & .867 & & & & & \\
\hline Current application procedures are simple to implement & .837 & & & & & \\
\hline Procedures of publicity and transparency & .764 & & & & & \\
\hline Procedures for reasonable settlement & .762 & & & & & \\
\hline Information on services is provided in full & 624 & & & & & \\
\hline Waiting time and transaction processing is appropriate & .577 & & & & & \\
\hline The public trust the quality of public administrative services & & .854 & & & & \\
\hline People are very confident in the use of public administrative services & & .861 & & & & \\
\hline Public administrative services always carry out what they have committed & & .767 & & & & \\
\hline The service provides people with high accuracy & & .732 & & & & \\
\hline Have counseling, explain to the people & & & .785 & & & \\
\hline There is a hotline & & & .721 & & & \\
\hline Procedures for resolving scientific complaints & & & .642 & & & \\
\hline The information system is appropriate & & & .635 & & & \\
\hline Full public fees and charges for workplaces & & & & .880 & & \\
\hline The time for returning the dossier-settling results is right & & & & .843 & & \\
\hline To collect fees and charges in accordance with regulations & & & & .778 & & \\
\hline Procedures for resolving scientific complaints & & & & & .765 & \\
\hline Very responsible in the work & & & & & .712 & \\
\hline Polite, agile behavior & & & & & .656 & \\
\hline Processing accurate records & & & & & .634 & \\
\hline Modern equipment & & & & & & .767 \\
\hline Standby area and receive separate results & & & & & & .754 \\
\hline Place convenient, easy to find, easy to see & & & & & & .743 \\
\hline Eigenvalues & 7.060 & 2.498 & 2.392 & 1.734 & 1.251 & 1.062 \\
\hline Eigenvalues explained $\%$ & 29.417 & 10.409 & 9.968 & 7.223 & 5.214 & 3.283 \\
\hline Cumulative explained \% & 29.417 & 39.826 & 49.794 & 57.018 & 62.23 & 65.514 \\
\hline
\end{tabular}

The research results, 2017

\subsection{Analyzing the EFA Factor}

The research model has 6 factors with 27 variables that affect each of the public administration service quality and affect the level of satisfaction of citizens in the Central Highlands. Considering the $\mathrm{KMO}=0.817>0.5$ and $\mathrm{p}=$ 0.000 , the hypothesis H0 "unrelated variables" is rejected. So analyzing the EFA factor is the right approach. At the same time, to identify the quantity of factors involved in the analysis, use the Total Variance Explained matrix. According to the Eigenvalues standard $>1$, six factors are taken into account and these six factors explain 65,514\% variation in the observed variables. Based on the six factorial rotation matrix at run-time, the EFA has 24 variable observations, the remainder being categorized into six factors and three variables eliminated. These are the information of the people are always good security; Always be fair to everyone and Waiting time for receiving and processing applications quickly

\subsection{The Regression Results}

Research will conduct a regression analysis to identify factors that affect people's satisfaction.

The regression function is as follows:

$$
\begin{gathered}
\mathrm{HL}=\beta \mathrm{o}+\beta 1 * \mathrm{QT}+\beta 2 * \mathrm{DTC}+\beta 3 * \mathrm{HT}+\beta 4 * \mathrm{CP}+ \\
+\beta 5^{*} \mathrm{DN}+\beta 6^{*} \mathrm{CS}+\mathrm{Ui}
\end{gathered}
$$

Regression results showed that 6 factors had positive and statistically significant coefficients with $\operatorname{sig}<0.05$. This 
suggests a positive relationship between the six factors and citizen satisfaction. This result is consistent with the research hypothesis. At the same time, the regression coefficient of the procedural factor was highest, reaching $\beta 1=0.339$ followed by citizen support and care $(\beta 3=$ $0.256)$ and time and cost $(\beta 4=0.234)$. As a result, procedural processes are the most influential factor in the satisfaction of citizens. The least impact factor is the reliability factor with $\beta 2=0.104$.

Table 6. The coefficient

\begin{tabular}{|c|c|c|c|c|c|c|}
\hline \multirow{2}{*}{\multicolumn{2}{|c|}{ Model }} & \multicolumn{2}{|c|}{$\begin{array}{l}\text { Unstandardized } \\
\text { coefficients }\end{array}$} & \multirow{2}{*}{$\begin{array}{c}\begin{array}{c}\text { Standardized } \\
\text { coefficients }\end{array} \\
\text { Beta }\end{array}$} & \multirow[t]{2}{*}{$\mathrm{t}$} & \multirow{2}{*}{ Sig. } \\
\hline & & B & Std. Error & & & \\
\hline \multirow{7}{*}{1} & $\mathrm{C}$ & 1.914 & .192 & & 9.985 & .000 \\
\hline & QT & .339 & .082 & .394 & 4.152 & .000 \\
\hline & DTC & .104 & .066 & .137 & 2.442 & .016 \\
\hline & $\mathrm{HT}$ & .256 & .087 & .262 & 2.553 & .001 \\
\hline & $\mathrm{CP}$ & .234 & .092 & .193 & 2.456 & .002 \\
\hline & $\mathrm{DN}$ & .124 & .085 & .183 & 3.050 & .000 \\
\hline & $\mathrm{CS}$ & .141 & .076 & .156 & 4.067 & .009 \\
\hline
\end{tabular}

The research results, 2017

\section{Recommendations to Improve the Quality of Public Administrative Services in Kon Tum Province}

\subsection{Completing the Procedure}

At present, the central highland is applying the one-stop-shop mechanism and inter-agency one-stop-shop mechanism at state administrative agencies. However, provinces in the Central Highlands have not applied the electronic one door system like other provinces in Vietnam. The "electronic one-door" public administrative service will facilitate individuals and organizations that need to quickly resolve administrative procedures at a single access site. People can check the status of records processing via the internet. This helps to shorten the process, reduce costs and time, and reduce fraud in the processing of records and procedures. Therefore, the provinces should invest in special infrastructure information system to progress to apply electronic door.

Besides, it helps to set up unexpected and periodical inspection teams to evaluate the implementation of administrative reform in localities in the provinces. From there, propose solutions to shorten the process in the most reasonable way.

\subsection{Improving the Quality of the Civil Servants and Officials}

The civil servants and officials are those who directly carry out public administrative services. They must be familiar with the procedures and policies related to the public administration they carry and the parties involved. Therefore, it is necessary to open regular training courses, professional training and dissemination of new relevant policies for staff. Particularly, the informatics and foreign language training for the civil servants are enhanced to be able to apply the electronic one-door model in the future.

Beside expertise, the attitude and ethics of civil servants and officials are very important. This is a relatively strong factor affecting the satisfaction of citizens in the province. Therefore, it's a must to raise the sense of responsibility, enthusiasm in work and resolutely fight the violations of law and ethics.

\subsection{Promotinh Care and Support for the People}

Satisfying people with public administrative services, care and support is important. If citizens are assisted and supplied with the procedures, they will be prepared in full, shortening waiting time. The provinces should stipulate that it is compulsory for public administrative units to clearly define the functions and tasks of the unit. Because, lots of people do not know whether this is the place where the carry out or not

The central highlands also surveys on the satisfaction of the public with regard to public administrative services and also gives some results as nearly $90 \%$ of the people are satisfied with the results of issuing birth certificates. At the same time, the level of satisfaction of organizations and individuals on the whole process of approving the construction permit was 67\% (Quang Dinh[17]). This is the evidence for the Provincial People's Committee to recognize the situation in the provincial departments and propose solutions to improve the quality of service and the benefit of organizations and individuals. However, at present, public administrative office in the province do not have any survey to collect opinion of people. Therefore, each office should actively collect opinions from people after implementing public services. This is the proof for improving the quality of public administrative services through assessment and aspirations of the people.

\section{Conclusions}

Assessing the level of satisfaction of organizations and individuals for public administrative services contributes to administrative reform in order to better serve the people. The study was conducted in 2017 by randomly interviewing 2000 citizens in the central highlands of Vietnam.

SPSS was used to test Cronbach's alpha and analyze EFA and run regression to assess citizens' satisfaction on the quality of public administrative services in the central 
highlands. The results of the study have identified six groups of factors that affect the satisfaction of citizens is reliability; procedures; cost and time; employers, civil servants and officials; facilities and care, supporting. All factors have a positive impact on people's satisfaction, especially procedures; supporting; cost and time are the most significant factors. Therefore, research has recommended some solutions to improve people's satisfaction, such as completing the process; improving the quality of cadres, civil servants and officials; promoting care and supporting people.

\section{REFERENCES}

[1] Bovaird, T., \& Löffler, E., Public management and governance, London and Newyork: Taylor \& Francis Group, 138-144, 1996.

[2] Chau Dam Trinh, Evaluation of people's satisfaction on compensation and site clearance services: Case study on compensation, support and resettlement project for Song Hau Industrial Park, Hau Giang province, Master thesis, Nha Trang University, Vietnam, 2012.

[3] Che Viet Phuong, Assessing the level of satisfaction of people with respect to the quality of public administrative services under the one-stop-shop mechanism at Cua Lo Town, Nghe An Province, Thesis dissertation, Nha Trang University, Vietnam, 2014.

[4] Cronin, J. J. \& Taylor, S. A., Measuring Service Quality: A Reexamination and Extension, Journal of Marketing, 56 (July): 55-68, 1992.

[5] General Statistics of Vietnam, The socio-economic situation in the Central highlands in 2017. Online available from http://thongkekontum.gov.vn/xem-tin-tuc.aspx?id=20480.

[6] Government, Decree No. 43/2011 / ND-CP dated 13/06/2011 of the Government, Vietnam, 2011.

[7] Grönroos, C., A service quality model and its marketing implications, European Journal of marketing, 18(4), 36-44, 1984.

[8] Hoai Tien, A electronic one door but ... still hand made. Online available from

http://baokontum.com.vn/toa-soan-ban-doc/mot-cua-dien-t u-nhung-van-lam-bang-tay-5636.html. 2017

[9] Kotler, P., Marketing Insights from A to Z, John Wiley \& Sons, Inc, USA, 2003.
[10] Le Dan, The Satisfaction Survey on Public Administrative Services of Citizens and Organizations, Journal of Science and Technology, University of Da Nang, No. 3 (44) 2011, p. 163-168, 2011.

[11] Ngo Dinh Trang, Research on customer satisfaction with business registration services of Department of Planning and Investment of Da Nang City, Master thesis, University of Economics, University Study Da Nang, Vietnam, 2009.

[12] Nguyen Thi Tram Anh và Nguyen Dinh Manh, Researching on citizens' satisfaction in using public services related tp the land sector in nghia dan district, nghe an province, Vietnam trade and industry review, No2. 2017.

[13] Oliver, R.L. and Satisfaction, A Behavioral Perspective on the Customer, M. E. Sharpe, New York, 1997.

[14] Parasuraman, A., Zeithaml, V. A., \& Berry, L. L., Servqual: A multiple-item scale for measuring consumer perc. Journal of retailing, 64(1), 12, 1988.

[15] Parasuraman, A., Zeithaml, V.A., and Berry, L.L., "A conceptual model of service quality and its implications for future research", Journal of Marketing, Vol. 49, No. 4, pp. 41-50, 1985.

[16] PCI, The provincial competitiveness index (PCI). Online available from http://pcivietnam.org/bang-xep-hang/, 2018.

[17] Quang Dinh, Announcement of results of survey on organizational and individual satisfaction of the service of state administrative agencies. Online available from http://baokontum.com.vn/xa-hoi/cong-bo-ket-qua-khao-sat -su-hai-long-cua-to-chuc-va-ca-nhan-doi-voi-su-phuc-vu-c ua-cac-co-quan-hanh-chinh-nha-nuoc-6429.html, 2017.

[18] Seth, N., Deshmukh, S. G., \& Vrat, P., Service quality models: a review, International journal of quality \& reliability management, 22(9), 913-949, 2005.

[19] Tran Quoc Huy, Citizen Satisfaction assessment on quality of public administrative services in Konplong district, Kon Tum province. Master of Business Administration thesis of The University of Danang, Vietnam, 2016.

[20] Tran Thi Thanh Tam, The level of satisfaction of the people - a measure of the effectiveness of reform of judicial administration in court. Online available from https://tapchitoaan.vn/bai-viet/nhan-vat-su-kien/muc-do-ha i-long-cua-nguoi-dan-thuoc-do-hieu-qua-cai-cach-thu-tuchanh-chinh-tu-phap-tai-toan-an. 2018.

[21] Tse, D.K. \& Wilton, P.C., Model of Consumer Satisfaction Formation: An Extension, Journal of Marketing Research, 25: 204-212, 1988.

[22] Vu Quynh, Quality of public administrative services in Hanoi city. PhD thesis. Central Institute for Economic Management, Vietnam, 2017. 